\title{
固有振動数の変動最小化を目的とした 確率有限要素法に基づくロバスト設計法
}

片桐 章彦*1，戸井 武司 ${ }^{* 2}$

\section{Robust design to minimize eigen frequency variance of structure by stochastic finite element method}

\author{
Akihiko KATAGIRI ${ }^{* 1}$ and Takeshi TOI $^{* 2}$ \\ ${ }^{* 1}$ Chuo Univ. Graduate School of Science and Engineering \\ 1-13-27 Kasuga, Bunkyo-ku, Tokyo 112-8551, Japan \\ ${ }^{*}$ Chuo Univ. Department of Science and Engineering \\ 1-13-27 Kasuga, Bunkyo-ku, Tokyo 112-8551, Japan
}

\section{Received 24 April 2014}

\begin{abstract}
Recently, in a mechanical structure development focusing on noise and vibration, a numerical analysis like finite element method is the most famous method to expect and improve noise and vibration characteristics of the structure. However, the method is not taken account of uncertainties in structure like part shapes and connecting parts in many cases. It leads to differences between actual these characteristics and results from numerical analysis. And, the quality of the product is probably deteriorated by the uncertainties. Therefore, it is important to suppress the variation of the noise and vibration characteristics by the uncertainties, which is called robust design. In this paper, it is discussed about robust design method to minimize the variation of the eigen frequency by the uncertainties. The robust design method is based on stochastic finite element method and structural optimization. To evaluate the ability of the method, the robust design method is applied to an FE model and a spring mass system, and the method is also tested by the actual structure to confirm the performance.
\end{abstract}

Key words : Robustness, Uncertainty, Finite element method, Optimum design, Eigen frequency

\section{1. 緒言}

近年，機械製品の振動，騒音は製品を評価する上で重要な要素の一つとなっており，製品設計においては低振 動，低騒音化に向けた厳しい設計目標が課せられている。ささらに，開発期間短縮やコスト削減の要求から，有限 要素法などの数值解析を用いた振動騒音特性の予測, および対策検討が主流となりつつある. しかし，数值解析 の結果は理想化された状態の理論值であり，実際の機械製品で生じる部品形状や組み付け部のバラツキなど，不 確実性による振動騷音特性の変動は考慮されていない，不確実性の影響が大きい場合，対策以前より悪化してし まう可能性も否定できず，製品の品質に大きな損害を与えることとなる．そのため，これらの問題に対し，不確 実性の影響による振動騒音特性の変動を抑制する「ロバスト設計」なる概念が重要視されている．本研究では， 振動騒音特性の変動を最小化するロバスト設計法を，数值解析を用いて開発することを目的とする.

構造物の不確実性に着目した研究は従来からなされており，その代表例としてモンテカルロシミュレーション やタグチメソッドなどがあげられる（Durand, et al., 2005）（星野，石井，2000)。しかし，これらの手法は不確実 性を持つと考えられる因子（以下，誤差因子）の影響把握や，応答変動を抑制するための因子（以下，制御因子） の最適值探索のために，異なるパターンのバラツキを誤差因子に与える複数回の計算が必ず必要となる. したが って，誤差因子，制御因子が多い場合，非現実的な計算時間となり，問題によっては対策案の検討が困難となる

No.14-00227 [DOI: 10.1299/transjsme.2014dr0329]

*1 正員, 中央大学 大学院 理工学研究科（率112-8551 東京都文京区春日 1-35-27)

*2 正員, 中央大学 理工学部

E-mail of corresponding author: akihiko_katagiri@camal.mech.chuo-u.ac.jp 
可能性がある.

誤差因子，制御因子が多い場合でも有効なロバスト設計法として，摂動法や偏微分勾配を利用し不確実性によ る応答変動を近似式で表寸確率有限要素法が提案されている（中桐，久田，1985）。この方法により応答変動に対 する誤差因子の影響度を把握でき，また構造最適化と組み合わせることで応答変動を抑制する制御因子の組み合 わせを検討することができる，ただし，その適用には不確実性が部品板厚や物性值のバラツキなどのパラメトリ ックな不確実性であること，誤差因子のバラツキ幅が小さく近似式が成立する範囲内であることという制約が課 せられており，これらの制約から実際の適用事例は限定され，特に振動問題での適用例は多くない，振動問題へ の適用として筆者らは，パラメトリックな不確実性を持つ構造物を対象に，確率有限要素法と構造最適化を組み 合わせたロバスト設計法（以下，ロバスト最適化）を提案し，周波数応答関数の振幅の変動に対し適用すること で一定の成果を得ている（古屋他，2014）.

そこで本論文では，筆者らが提案した確率有限要素法と構造最適化を組み合わせたロバスト最適化を利用し， 振動騒音特性の基本特性である固有振動数の変動を最小化する構造（以下，ロバス卜構造）を求める. 先行研究 として固有振動数の変動を対象とした数值解析を用いたロバスト設計が示されているが（廣安他，1996）, 解析結 果のみであり，また制御因子と誤差因子の区別をしておらず，その点の考察がなされていない．実際の機械製品 では，制御因子と誤差因子を明確にして対策の検討が行われることが多い．そこで本論文では，制御因子と誤差 因子を区別してロバスト最適化を行い, その際のロバスト構造の物理的な特徵を固有モードの変化から考察する. また，前報では実施していない実験による計算結果の妥当性の検証を行い，提案する確率有限要素法と構造最適 化を組み合わせたロバスト最適化の結果の妥当性を示す．本論文の第 2 章では，まず固有振動数に対する確率有 限要素法と構造最適化を組み合わせたロバスト最適化の理論を説明し，次に最適化問題を解く際に利用する固有 振動数の一次感度および二次感度の導出を行う. 第 3 章では, バネマス系と簡易有限要素モデルにロバスト最適 化を適用し，その有効性の確認を行い，ロバスト構造の物理的な特徵を固有モードから考察する. さらに第 4 章 では，簡易有限要素モデルの結果に基づき試験片を加工し，実験によりロバスト最適化の妥当性の検証を行う. なお，本論文では誤差因子のバラツキは互いに無相関で，変動係数が同じ值であることを前提に議論を行う。

\section{2. 固有振動数に対する確率有限要素法と構造最適化を組み合わせたロバスト最適化}

本章では固有振動数に対する確率有限要素法と構造最適化を組み合わせたロバスト最適化を説明する．まず $2 \cdot 1$ 節で, 確率有限要素法に従い固有振動数を誤差因子の一次感度までを考慮した一次近似モデルで表す。この とき固有振動数の変動は, 誤差因子の固有振動数に対する一次感度と誤差因子のバラツキ幅をあらわした共分散 行列の積で近似できる. よって誤差因子のバラツキ幅を抑制する, あるいは誤差因子の一次感度を最小化するこ とで固有振動数の変動を最小化可能であり, 本論文では誤差因子の一次感度を目的関数, 制御因子を最適化の設 計変数とした構造最適化を適用寸る.この構造最適化をロバスト最適化と呼ぶ. ロバスト最適化により固有振動 数の変動を最小化する制御因子の值を求めることができる. $2 \cdot 2$ 節では上述のロバスト最適化を説明し， $2 \cdot 3$ 節では最適化問題を逐次線形計画法で解く際に必要となる誤差因子の固有振動数に対する一次感度と, 一次感度 を制御因子で偏微分した二次感度を説明する.

\section{$2 \cdot 1$ 確率有限要素法に基づいた固有振動数の一次近似モデル}

確率有限要素法は応答を誤差因子でテイラー展開し, 誤差因子の変化による応答の変化を誤差因子の応答に対 する勾配（感度）と誤差因子の変化量（バラツキ幅）で近似する方法である. $r$ 次の固有振動数 $f_{r}$ を誤差因子の 期待值 $\boldsymbol{\alpha}=\left\{\alpha_{1}, \alpha_{2}, \cdots, \alpha_{\mathrm{n}}\right\}$ のまわりでテイラー展開すると, 各因子が $d \alpha_{i}$ 変化したときの固有振動数は次式で近似 できる.

$$
f_{r}(\boldsymbol{\alpha}+\Delta \boldsymbol{\alpha})=f_{r}(\boldsymbol{\alpha})+\sum_{i=1}^{n} \frac{\partial f_{r}(\boldsymbol{\alpha})}{\partial \alpha_{i}} d \alpha_{i}+\frac{1}{2} \sum_{i=1}^{n} \sum_{j=1}^{n} \frac{\partial^{2} f_{r}(\boldsymbol{\alpha})}{\partial \alpha_{i} \partial \alpha_{j}} d \alpha_{i} d \alpha_{j}+\cdots
$$

ここで $\Delta \boldsymbol{\alpha}$ は各因子の変化量 $\Delta \boldsymbol{\alpha}=\left\{d \alpha_{1}, d \alpha_{2}, \ldots, d \alpha_{n}\right\}, n$ は誤差因子の数を表す. 式（1）右辺第 2 項の一次感度まで 採用した近似式は一次近似モデルと呼ばれる。一次近似モデルにより $d \alpha_{i}$ が十分小さいという条件下で, 誤差因 
子の変化による固有振動数の変化を予測可能となる.さらに，このときの固有振動数 $f_{r}(\boldsymbol{\alpha}+\Delta \boldsymbol{\alpha})$ の期待值 $\mathrm{E}\left[f_{r}(\boldsymbol{\alpha}+\Delta \boldsymbol{\alpha})\right]$ と分散 $\operatorname{Var}\left[f_{r}(\boldsymbol{\alpha}+\Delta \boldsymbol{\alpha})\right]$ は次式で表される.

$$
\begin{aligned}
& \mathrm{E}\left[f_{r}(\boldsymbol{\alpha}+\Delta \boldsymbol{\alpha})\right]=f_{r}(\boldsymbol{\alpha}) \\
& \operatorname{Var}\left[f_{r}(\boldsymbol{\alpha}+\Delta \boldsymbol{\alpha})\right]=\sum_{i=1}^{n} \sum_{j=1}^{n} \frac{\partial f_{r}(\boldsymbol{\alpha})}{\partial \alpha_{i}} \frac{\partial f_{r}(\boldsymbol{\alpha})}{\partial \alpha_{j}} \mathrm{E}\left[d \alpha_{i} d \alpha_{j}\right]=\mathbf{s}_{1}^{\mathrm{T}} \mathbf{V} \mathbf{s}_{1} \\
& \mathbf{s}_{1}=\left\{\begin{array}{lll}
\frac{\partial f_{r}(\boldsymbol{\alpha})}{\partial \alpha_{1}} & \cdots & \frac{\partial f_{r}(\boldsymbol{\alpha})}{\partial \alpha_{n}}
\end{array}\right\}^{\mathbf{T}} \\
& \mathbf{V}=\left[\begin{array}{ccc}
\operatorname{Var}\left[\alpha_{1}\right] & \cdots & \operatorname{Cov}\left[\alpha_{1}, \alpha_{n}\right] \\
& \ddots & \vdots \\
\operatorname{SYM} . & & \operatorname{Var}\left[\alpha_{n}\right]
\end{array}\right]
\end{aligned}
$$

ここで $\operatorname{Cov}$ は共分散を表す. 式（3）より，固有振動数 $f_{r}(\boldsymbol{\alpha}+\Delta \boldsymbol{\alpha})$ の分散 $\operatorname{Var}\left[f_{r}(\boldsymbol{\alpha}+\Delta \boldsymbol{\alpha})\right]$ は一次感度のベクトル $\mathbf{s}_{1}$ と 誤差因子のバラツキ幅で決まる共分散行列 $\mathbf{V}$ の積で近似でき，固有振動数の変動すなわち分散を小さくするため には一次感度を小さくする，あるいは，誤差因子のバラツキ幅を抑制する必要があることがわかる.

本論文では誤差因子のバラツキ幅を抑制せずに固有振動数の変動を小さくすることを目的としているため，一 次感度を小さくするロバスト最適化を検討する.また本論文で取り扱う誤差因子は, バラツキが互いに無相関で, かつ同じ変動係数值を持つと仮定しており，その場合，式（3）（4）（5）は簡略化できる. その説明のために式 (3) の分散 $\operatorname{Var}\left[f_{r}(\boldsymbol{\alpha}+\Delta \boldsymbol{\alpha})\right.$ ] 次式のように誤差因子の期待值 $\alpha_{i}$ を乗じた感度 $\mathbf{s}_{1}^{\prime}$ と誤差因子の期待值で除した共分散行 列 $\mathbf{V}^{\prime}$ 積で表す.

$$
\begin{aligned}
& \operatorname{Var}\left[f_{r}(\boldsymbol{\alpha}+\Delta \boldsymbol{\alpha})\right]=\mathbf{s}_{1}^{\mathrm{T}} \mathbf{V} \mathbf{s}_{1}=\mathbf{s}_{1}^{\prime \mathrm{T}} \mathbf{V}^{\prime} \mathbf{s}_{1}^{\prime} \\
& \mathbf{s}_{1}^{\prime}=\left\{\alpha_{1} \frac{\partial f_{r}(\boldsymbol{\alpha})}{\partial \alpha_{1}} \quad \cdots \quad \alpha_{n} \frac{\partial f_{r}(\boldsymbol{\alpha})}{\partial \alpha_{n}}\right\}^{\mathbf{T}} \\
& \mathbf{V}^{\prime}=\left[\begin{array}{ccc}
\frac{\operatorname{Var}\left[\alpha_{1}\right]}{\alpha_{1}^{2}} & \cdots & \frac{\operatorname{Cov}\left[\alpha_{1}, \alpha_{n}\right]}{\alpha_{1} \alpha_{n}} \\
& \ddots & \vdots \\
\operatorname{SYM} & & \frac{\operatorname{Var}\left[\alpha_{n}\right]}{\alpha_{n}^{2}}
\end{array}\right]=\left[\begin{array}{ccc}
C_{\mathrm{v}, 1}^{2} & \cdots & \frac{\operatorname{Cov}\left[\alpha_{1}, \alpha_{n}\right]}{\alpha_{1} \alpha_{n}} \\
& \ddots & \vdots \\
\operatorname{SYM} & & C_{\mathrm{v}, n}^{2}
\end{array}\right] \\
& C_{\mathrm{v}, i} \equiv \sqrt{\frac{\operatorname{Var}\left[\alpha_{i}\right]}{\alpha_{i}^{2}}}=\frac{\sigma\left[\alpha_{i}\right]}{\alpha_{i}}
\end{aligned}
$$

式（9）で表された $C_{\mathrm{v}, i}$ は変動係数（Coefficient of variation）と呼ばれ，誤差因子の標準偏差 $\sigma\left[\alpha_{i}\right]$ を期待值 $\alpha_{i}$ で正規 化した值である. そして誤差因子のバラツキが互いに無相関 $\left(\operatorname{Cov}\left[\alpha_{i}, \alpha_{j}\right]=0, i \neq j\right)$ で，同じ变動係数 $C_{\mathrm{v}}$ を持つ場 合，共分散行列 $\mathbf{V}^{\prime}$ は次式のように $C_{\mathrm{v}}$ を対角成分に持つ対角行列に変換できる.

$$
\mathbf{V}^{\prime}=C_{\mathrm{v}}^{2}\left[\begin{array}{lll}
1 & & 0 \\
& \ddots & \\
0 & & 1
\end{array}\right]
$$

\section{$2 \cdot 2$ 誤差因子の固有振動数に対する一次感度を目的関数としたロパスト最適化}

式（10）に示したように誤差因子のバラツキが互いに無相関で，かつ同じ変動係数值 $C_{\mathrm{v}}$ を持つ場合，共分散行 列 $\mathbf{V}^{\prime}$ は $C_{\mathrm{v}}$ を対角成分に持つ対角行列に変換できる. よって式（6）で表された固有振動数の分散 $\operatorname{Var}\left[f_{r}(\boldsymbol{\alpha}+\Delta \boldsymbol{\alpha})\right]$ 
に対する各誤差因子の影響度は, 誤差因子の期待值を乗じた一次感度 $\mathbf{s}_{1}$ で表される. そのため, 固有振動数の変 動を小さくするには，一次感度を小さくすればよい.

第 $2 \cdot 1$ 節で説明した固有振動数の一次近似モデルは, 因子の変化量が微小の場合に成立する.これは一次感度 を対象としても同様である，そのため近似式が成立する範囲内で，一次感度の近似式計算と一次感度を最小化す る制御因子を求める過程を繰り返すロバスト最適化により, 固有振動数の変動を最小化する最適な制御因子の值 を求める. 一次感度の一次近似モデルは次式となる.

$$
\frac{\partial f_{r}(\boldsymbol{\alpha}+\Delta \boldsymbol{\alpha})}{\partial \alpha_{i}}=\frac{\partial f_{r}(\boldsymbol{\alpha})}{\partial \alpha_{i}}+\sum_{j=1}^{n} \frac{\partial^{2} f_{r}(\boldsymbol{\alpha})}{\partial \alpha_{i} \partial \alpha_{j}} d \alpha_{j}
$$

ロバスト最適化の最適化計算は逐次線形計画法で解き, 目的関数は絶対值が最も大きい誤差因子の一次感度と する. ただし最適化過程で感度が最も大きい誤差因子が他の誤差因子と入れ替わることがあり，その入れ替わり の際に最適化の収束性が悪化する場合がある. そのため目的関数に設定した誤差因子以外の一次感度が目的関数 に設定した誤差因子の感度よりも小さくなるような制約条件を課す。この制約条件を課すことで最適化の収束性 が改善される. ロバスト最適化では上記の条件と質量一定の条件も課し制御因子を設計変数とする. 目的関数を 式 (12), 制約関数を式 (13), (14), 設計変数を式（15）にまとめる.

$$
\begin{array}{ll}
\text { Minimize : } & \operatorname{Max}\left(\left|\alpha_{i} \frac{\partial f_{r}(\boldsymbol{\alpha})}{\partial \alpha_{i}}\right|\right) \quad i \in \mathrm{N}_{\mathrm{F}} \\
\text { Subject to : } & \left|\alpha_{i} \frac{\partial f_{r}(\boldsymbol{\alpha})}{\partial \alpha_{i}}\right|<\operatorname{Max}\left(\left|\alpha_{i} \frac{\partial f_{r}(\boldsymbol{\alpha})}{\partial \alpha_{i}}\right|\right) \\
\text { mass = constant. } &
\end{array}
$$

Design variable : $\alpha_{j}$

$j \in \mathrm{C}_{\mathrm{F}}$

ここで， $\mathrm{N}_{\mathrm{F}}$ （Noise Factor）は誤差因子の集合， $\mathrm{C}_{\mathrm{F}}$ （Control Factor）は制御因子の集合を表す． $\mathrm{N}_{\mathrm{F}}$ と $\mathrm{C}_{\mathrm{F}}$ は独立で はなく誤差因子と制御因子は同じ因子（例えば同じ要素の板厚）の場合も考慮可能である.

\section{$2 \cdot 3$ 固有振動数の一次感度, 二次感度の導出}

上述したロバスト最適化を解く際に利用する, 誤差因子 $\alpha_{i}\left(i \in \mathrm{N}_{\mathrm{F}}\right)$ の固有振動数に対する一次感度（山川, 奥 村, 1976）と, 一次感度を制御因子 $\alpha_{j} \quad\left(j \in \mathrm{C}_{\mathrm{F}}\right)$ で偏微分した二次感度を導出する. 有限要素法で離散化された構 造物の固有值 $\lambda_{r}$ は次式で表される.

$$
\left(\mathbf{K}-\lambda_{r} \mathbf{M}\right) \phi_{r}=0
$$

ここで $\mathbf{M}, \mathbf{K}$ は質量, 岡性行列, $\lambda_{r}$ は $r$ 次の固有值, $\phi_{r}$ は $r$ 次の固有ベクトルを表す. 式（16）を誤差因子 $\alpha_{i}$ で 偏微分すると次式を得る.

$$
\left(\mathbf{K}-\lambda_{r} \mathbf{M}\right) \frac{\partial \phi_{r}}{\partial \alpha_{i}}+\left(\frac{\partial \mathbf{K}}{\partial \alpha_{i}}-\lambda_{r} \frac{\partial \mathbf{M}}{\partial \alpha_{i}}\right) \phi_{r}-\frac{\partial \lambda_{r}}{\partial \alpha_{i}} \mathbf{M} \phi_{r}=0
$$

式（17）の左から $\phi_{r}$ の転置 $\phi_{r}^{\mathrm{T}}$ を乗じると $\mathbf{M}, \mathbf{K}$ が対称行列でかつ式（16）が成立するため, 左辺の第 1 項はゼロ になり次式を得る．ただし $\phi_{r}$ は質量行列 $\mathbf{M}$ で正規化されているものとする. 


$$
\frac{\partial \lambda_{r}}{\partial \alpha_{i}}=\phi_{r}^{\mathbf{T}}\left(\frac{\partial \mathbf{K}}{\partial \alpha_{i}}-\lambda_{r} \frac{\partial \mathbf{M}}{\partial \alpha_{i}}\right) \phi_{r}
$$

また, $r$ 次の固有角振動数を $\Omega_{r}$ とすると $\Omega_{r}{ }^{2}=\lambda_{r}$ より, $r$ 次の固有角振動数の一次感度は次式で表される.

$$
\frac{\partial \Omega_{r}}{\partial \alpha_{i}}=\frac{1}{2 \Omega_{r}} \frac{\partial \lambda_{r}}{\partial \alpha_{i}}=\frac{1}{2 \Omega_{r}} \phi_{r}^{\mathbf{T}}\left(\frac{\partial \mathbf{K}}{\partial \alpha_{i}}-\lambda_{r} \frac{\partial \mathbf{M}}{\partial \alpha_{i}}\right) \phi_{r}
$$

式 (19) を $2 \pi$ で除算することで, $r$ 次の固有振動数 $f_{r}$ の一次感度が得られる.

次に二次感度を導出する. 式（17）の両辺を制御因子 $\alpha_{j}$ で偏微分すると次式を得る.

$$
\begin{gathered}
\left(\mathbf{K}-\lambda_{r} \mathbf{M}\right) \frac{\partial^{2} \phi_{r}}{\partial \alpha_{j} \partial \alpha_{i}}+\left(\frac{\partial^{2} \mathbf{K}}{\partial \alpha_{j} \partial \alpha_{i}}-\frac{\partial^{2} \lambda_{r}}{\partial \alpha_{j} \partial \alpha_{i}} \mathbf{M}-\frac{\partial \lambda_{r}}{\partial \alpha_{i}} \frac{\partial \mathbf{M}}{\partial \alpha_{j}}-\frac{\partial \lambda_{r}}{\partial \alpha_{j}} \frac{\partial \mathbf{M}}{\partial \alpha_{i}}-\lambda_{r} \frac{\partial^{2} \mathbf{M}}{\partial \alpha_{j} \partial \alpha_{i}}\right) \phi_{r} \\
+\left(\frac{\partial \mathbf{K}}{\partial \alpha_{j}}-\lambda_{r} \frac{\partial \mathbf{M}}{\partial \alpha_{j}}-\frac{\partial \lambda_{r}}{\partial \alpha_{j}} \mathbf{M}\right) \frac{\partial \phi_{r}}{\partial \alpha_{i}}+\left(\frac{\partial \mathbf{K}}{\partial \alpha_{i}}-\lambda_{r} \frac{\partial \mathbf{M}}{\partial \alpha_{i}}-\frac{\partial \lambda_{r}}{\partial \alpha_{i}} \mathbf{M}\right) \frac{\partial \phi_{r}}{\partial \alpha_{j}}=0
\end{gathered}
$$

式 (20) の左から $\phi_{r}$ の転置 $\phi_{r}{ }^{\mathrm{T}}$ 乗じると $\mathbf{M}, \mathbf{K}$ が対称行列でかつ式（16）が成立するため, 左辺の第 1 項はゼロ になり次式を得る.

$$
\begin{aligned}
\frac{\partial^{2} \lambda_{r}}{\partial \alpha_{j} \partial \alpha_{i}} & =\phi_{r}^{\mathrm{T}}\left(\frac{\partial^{2} \mathbf{K}}{\partial \alpha_{j} \partial \alpha_{i}}-\frac{\partial \lambda_{r}}{\partial \alpha_{i}} \frac{\partial \mathbf{M}}{\partial \alpha_{j}}-\frac{\partial \lambda_{r}}{\partial \alpha_{j}} \frac{\partial \mathbf{M}}{\partial \alpha_{i}}-\lambda_{r} \frac{\partial^{2} \mathbf{M}}{\partial \alpha_{j} \partial \alpha_{i}}\right) \phi_{r} \\
+ & \phi_{r}^{\mathbf{T}}\left(\frac{\partial \mathbf{K}}{\partial \alpha_{j}}-\lambda_{r} \frac{\partial \mathbf{M}}{\partial \alpha_{j}}-\frac{\partial \lambda_{r}}{\partial \alpha_{j}} \mathbf{M}\right) \frac{\partial \phi_{r}}{\partial \alpha_{i}}+\phi_{r}^{\mathbf{T}}\left(\frac{\partial \mathbf{K}}{\partial \alpha_{i}}-\lambda_{r} \frac{\partial \mathbf{M}}{\partial \alpha_{i}}-\frac{\partial \lambda_{r}}{\partial \alpha_{i}} \mathbf{M}\right) \frac{\partial \phi_{r}}{\partial \alpha_{j}}
\end{aligned}
$$

式（21）は誤差因子 $\alpha_{i}$ と制御因子 $\alpha_{j}$ 間の相互影響度を表寸相互感度であり， $i=j$ のき相互感度は二次感度と考 えることができる. なお $\partial \phi_{r} \partial \alpha_{i}$ と $\partial \phi_{r} \partial \partial \alpha_{j}$ は固有ベクトル $\phi_{r}$ に対する設計パラメータ $\alpha_{i}, \alpha_{j}$ の一次感度であり, 次 式で表される（萩原他，1986）.

$$
\begin{aligned}
& \begin{aligned}
\frac{\partial \phi_{r}}{\partial \alpha_{i}} & =\sum_{l=1}^{n} a_{r l} \phi_{r} \\
\text { if } \quad r & \neq l \\
a_{r l} & =\frac{1}{\lambda_{r}-\lambda_{l}} \phi_{l}^{\mathbf{T}}\left(\frac{\partial \mathbf{K}}{\partial \alpha_{i}}-\lambda_{r} \frac{\partial \mathbf{M}}{\partial \alpha_{i}}\right) \phi_{r} \\
\text { if } \quad r & =l \\
a_{r r} & =-\frac{1}{2} \phi_{r}^{\mathrm{T}} \frac{\partial \mathbf{M}}{\partial \alpha_{i}} \phi_{r}
\end{aligned}
\end{aligned}
$$

また, $\Omega_{r}{ }^{2}=\lambda_{r}$ より次式が成立し, 次式一式 (19) と式 (21) を代入することで固有角振動数の二次感度および相 互感度を求めることができる.

$$
\frac{\partial^{2} \Omega_{r}}{\partial \alpha_{i} \partial \alpha_{j}}=\frac{1}{2 \Omega_{r}}\left(\frac{\partial^{2} \lambda_{r}}{\partial \alpha_{j} \partial \alpha_{i}}-2 \frac{\partial \Omega_{r}}{\partial \alpha_{i}} \frac{\partial \Omega_{r}}{\partial \alpha_{j}}\right)
$$


また式（23）を $2 \pi て ゙$ 除算することで固有振動数 $f_{r}$ の二次感度および相互感度が得られる.

\section{3. バネマス系へのロバスト最適化の適用}

本章では 2 章で説明したロバスト最適化を図 1 に示す 5 自由度バネマス系に適用し，一次感度の絶対值を最小 化することで固有振動数の変動を抑制できることを確認する. また得られたロバスト構造の物理的な特徵を, 固 有モードの変化から考察する. バネマス系の各パラメータは $m_{i}=10 \mathrm{~kg}, k_{i}=1.0 \times 10^{7} \mathrm{~N} / \mathrm{m}, c_{i}=1.0 \times 10^{2} \mathrm{Ns} / \mathrm{m}(i=1 \sim 5)$ とし, 固有振動数の変動の大きさの比較には, 平均值 $M$ (Mean), 標準偏差 $\sigma$, 変動係数 $C v=\sigma M$ (Coefficient of variation）を用いる.

\section{$3 \cdot 1$ 質量がバラツキを持つ場合}

始めに質量がバラツキを持つ場合を考える. 誤差因子を質点 3 の質量 $m_{3}$ とし, $m_{3}$ がバラついた際の 3 次固有 振動数 $f_{3}$ の変動を最小化することを目的に, $m_{3}$ の $f_{3}$ に対する一次感度をロバスト最適化により最小化する. 制御 因子は質点 3 以外の質量とし, 許容変化量を $\pm 50 \%$, 制御因子の質量の和は最適化前と同一（質量一定）の条件 下で最適化計算を行う。

図 2 にロバスト最適化による一次感度の推移を示す．横軸に構造最適化の繰り返し計算回数, 縦軸に一次感度 の絶対值を示しており, 最適化計算により一次感度がほぼゼロまで収束している様子がわかる. これより，ロバ ス卜最適化は安定的に実行されていることがわかる. 表 1 にロバスト構造の制御因子の值を示す. 誤差因子の $m_{3}$ より小さい添え字の質点は質量が小さく, 大きい添え字の質点は質量が大きな構造に変化している.

一次感度の減少により実際に固有振動数の変動が抑制されたかを, 初期構造, ロバスト構造の誤差因子 $m_{3}$ にそ れぞれバラツキを与え, その際の固有振動数の変動の比較により検証する. $m_{3}$ のバラツキ幅は標準偏差 $\sigma=0.5 \times$ 初期板厚の正規分布に従い, ランダムで $N=300$ 回計算を行った. 表 2 に 3 次固有振動数の変動の大きさの比較を まとめ, 図 3 に FRF の変動の比較を示す. FRF の入力点は質点 1 , 応答点は質点 5 とした. 表 2 の $f_{3}$ は確定論的 に求めた 3 次固有振動数, $M\left(f_{3}\right)$ は 300 回の平均固有振動数, $\sigma\left(f_{3}\right), C v\left(f_{3}\right)$ は標準偏差, 变動係数を表す. 今回の構造最適化では固有振動数の増減の条件は付与していないが, ロバスト構造では 3 次固有振動数が約 $2.2 \%$ 増加した. 変動係数を比較すると, 初期構造 $2.3 \%$ に対してロバスト構造ではほぼゼロになっており, 固有振動 数の変動が抑制できていることがわかる. また, 図 3 からもロバスト構造では 3 次固有振動数の変動が抑制され ている様子が確認できる.

ここで得られたロバスト構造の物理的な特徵を, 固有モードから考察する. 図4 亿初期構造, ロバスト構造の 3 次固有モードを示寸. 初期構造では誤差因子の質点 3 が振幅を持つ一方で, ロバスト構造では誤差因子が節点 になっており，質量のバラツキの影響を受けない構造に変化している．つまりロバスト最適化は，固有モードに おける誤差因子の質点を節点に変化させるような構造変更を行っていることがわかる．これより質量が誤差因子 の場合は, 固有モードにおいて誤差因子が節点となる構造的特徵があり，そのような構造設計を行なうことで固 有振動数の変動に対するロバスト性を高めることが可能である.

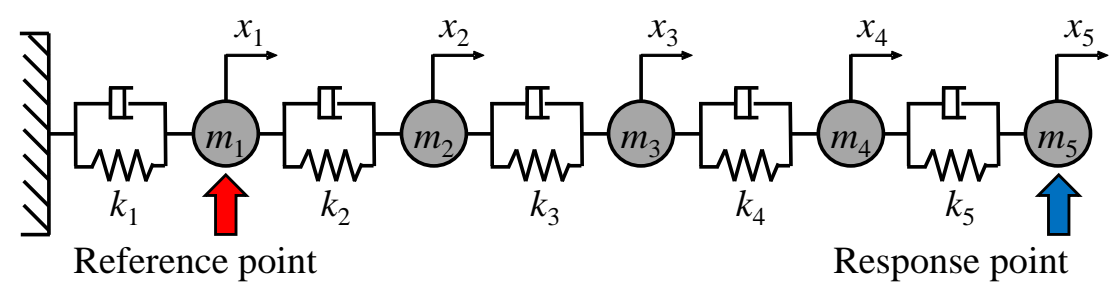

Fig. 1 Spring-mass systems of 5 degree of freedom 


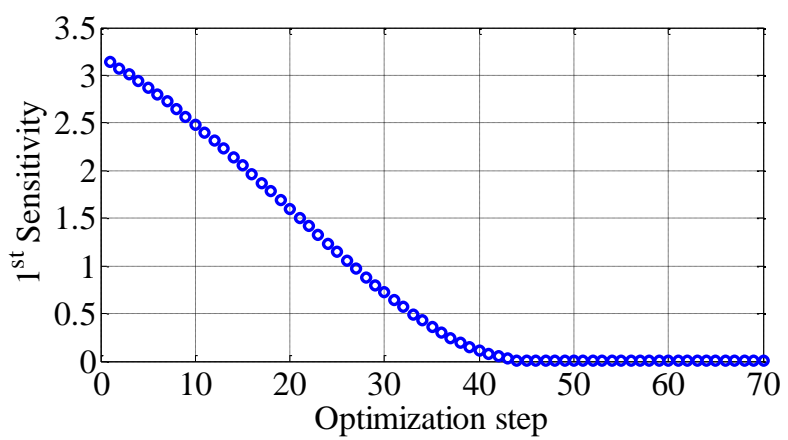

Table 1 Change of control factor parameter

\begin{tabular}{|c|c|c|c|c|}
\hline & $m_{1}$ & $m_{2}$ & $m_{4}$ & $m_{5}$ \\
\hline Original & 10.00 & 10.00 & 10.00 & 10.00 \\
\hline Robust & 6.04 & 5.08 & 14.87 & 14.00 \\
\hline
\end{tabular}

Fig. $21^{\text {st }}$ sensitivity under robust optimization. It shows that robust optimization is performed stably.

Table 2 Comparison of the robustness at $3^{\text {rd }}$ eigen frequency. It shows that the robustness is improved by comparing $C v$.

\begin{tabular}{|c|c|c|c|c|}
\hline & $f_{3}[\mathrm{~Hz}]$ & $M\left(f_{3}\right)[\mathrm{Hz}]$ & $\sigma\left(f_{3}\right)[\mathrm{Hz}]$ & $C v\left(f_{3}\right)[\%]$ \\
\hline Original & 208.4 & 208.9 & 4.8 & 2.30 \\
\hline Robust & 213.0 & 213.0 & $2.2 \times 10^{-7}$ & 0.00 \\
\hline
\end{tabular}

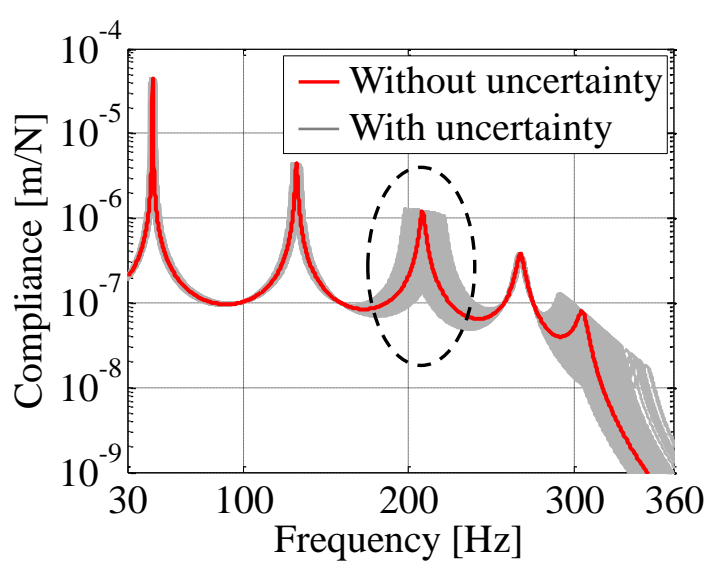

(a) Original structure

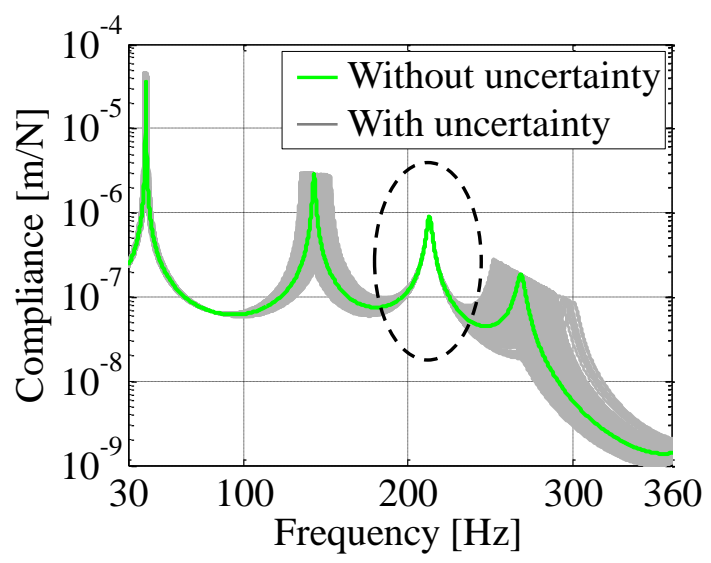

(b) Robust structure

Fig. 3 Comparison of FRF variation between original and robust structure. It shows that $3^{\text {rd }}$ eigen frequency variation is suppressed.

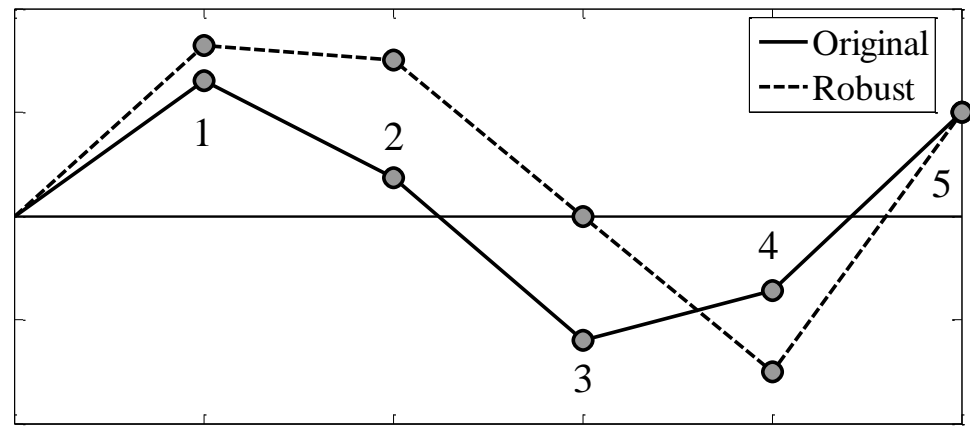

Fig. 4 Comparison of $3^{\text {rd }}$ eigen mode between original and robust structure. It shows that it has changed the strucuture, which the noise factor became nodal point by robust optimization.

\section{$3 \cdot 2$ 剛性がバラッキを持つ場合}

次に剛性がバラツキを持つ場合を考える. 誤差因子を質点 2 と質点 3 を結ぶバネ剛性 $k_{3}$ とし， $k_{3}$ がバラツいた 際の 3 次固有振動数 $f_{3}$ の変動を最小化することを目的に, $k_{3}$ の $f_{3}$ に対する一次感度を構造最適化により最小化す る. 制御因子は $k_{3}$ 以外のバネ剛性とし, 許容変化量を $\pm 50 \%$, 制御因子の剛性の和は最適化前と同一 (岡性一定) の条件下で最適化計算を行う. 
図 5 に構造最適化による 1 次感度の推移を示す. 質量がバラツキを持つ場合と同様に, 最適化計算により一次 感度がほぼゼロに収束している様子が分かる。これより，ロバスト最適化は安定的に実行されていることがわか る. 表 3 にロバスト構造の制御因子の值を示す．誤差因子の $k_{3}$ より小さい添え字のバネ剛性が小さく，大きい添 え字のバネ剛性は大きい構造へと変化している.

一次感度の減少により固有振動数の変動が抑制されたかを, 初期構造, ロバスト構造の誤差因子 $k_{3}$ にそれぞれ バラツキを与え, その際の固有振動数の変動の比較により検証する. $k_{3}$ のバラツキ幅は標準偏差 $\sigma=0.5 \times$ 初期板 厚の正規分布に従い, ランダムで $N=300$ 回計算を行った. 表 4 に 3 次固有振動数の変動の大きさの比較をまとめ,

図 6 に FRF の変動の比較を示す. 表 4 より, 構造最適化で固有振動数の増減の条件は付与していないが，ロバス 卜構造では 3 次固有振動数が約 $8.1 \%$ 減少した. 変動係数を比較すると, 初期構造 $2.49 \%$ に対してロバスト構造 ではほぼゼロになり，剛性がバラツキを持つ場合でもロバスト最適化により固有振動数の変動を抑制できている ことがわかる. また，図 6 からもロバスト構造では 3 次固有振動数の変動が抑制されている様子が確認できる.

ロバスト構造の物理的な特徵を, 固有モードから考察する. 図 7 に初期構造, ロバスト構造の 3 次固有モード を示す．初期構造では誤差因子のバネを結ぶ質点 2 と質点 3 が異なる振幅で振動している一方，ロバスト構造で は質点 2 と質点 3 の相対振幅がゼロとなっており,振動時のバネの伸縮が小さくなるような構造に変化している. つまりロバスト最適化は，固有モードにおける誤差因子の伸縮が小さくなるような構造変更を行っていることが わかる.これより剛性が誤差因子の場合は, 固有モードにおいて誤差因子のバネが伸縮しない構造的特徵があり, このような構造設計を行なうことで固有振動数の変動に対するロバス卜設計を行なうことが可能である.

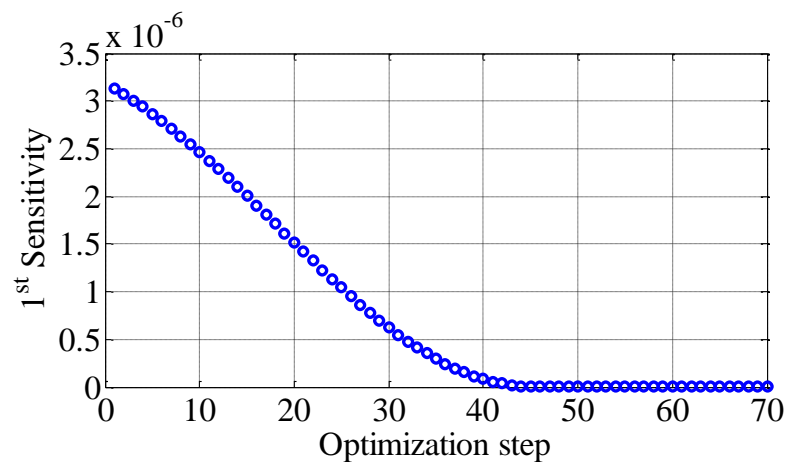

Table 3 Change of control factor parameter $[\mathrm{N} / \mathrm{m}]$

Fig. $5 \quad 1^{\text {st }}$ sensitivity under robust optimization. It shows that robust optimization is performed stably.

Table 4 Comparison of the robustness at $3^{\text {rd }}$ eigen frequency. It shows that the robustness is improved by comparing $C v$.

\begin{tabular}{|c|c|c|c|c|}
\hline & $f_{3}[\mathrm{~Hz}]$ & $M\left(f_{3}\right)[\mathrm{Hz}]$ & $\sigma\left(f_{3}\right)[\mathrm{Hz}]$ & $C v\left(f_{3}\right)[\%]$ \\
\hline Original & 208.4 & 207.4 & 5.2 & 2.49 \\
\hline Robust & 191.5 & 191.5 & $4.3 \times 10^{-9}$ & 0.00 \\
\hline
\end{tabular}

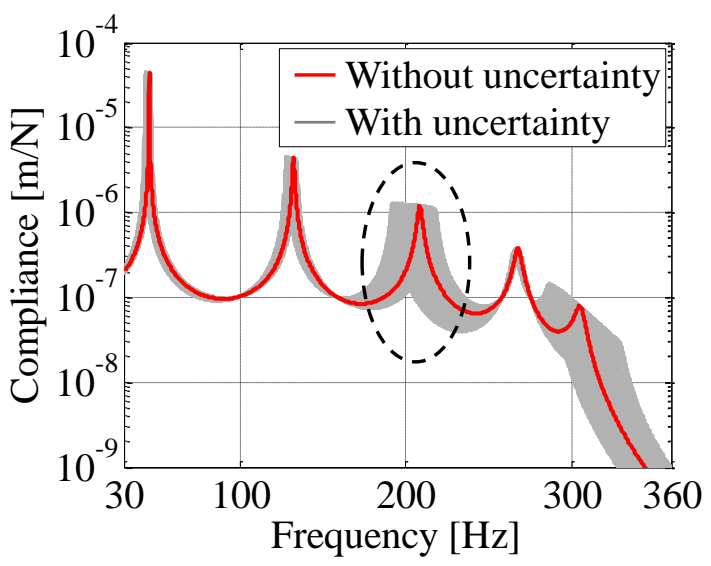

(a) Original structure

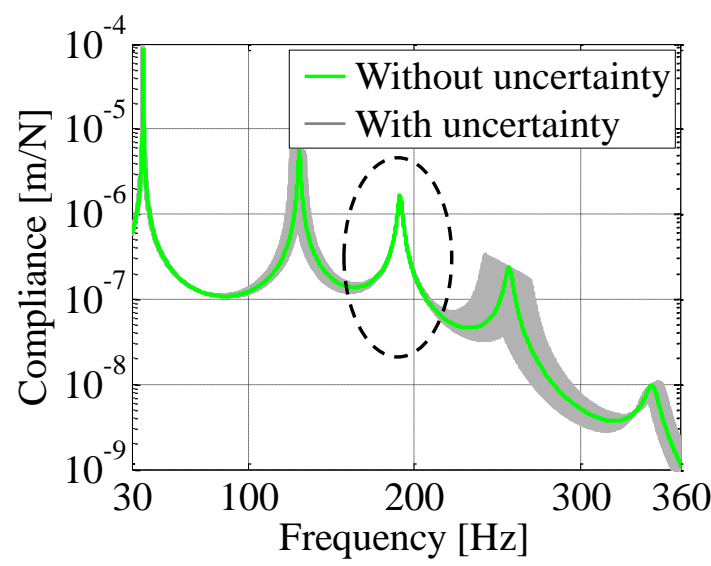

(b) Robust structure

Fig. 6 Comparison of FRF variation between original and robust structure. It shows that $3^{\text {rd }}$ eigen frequency variation is suppressed. 


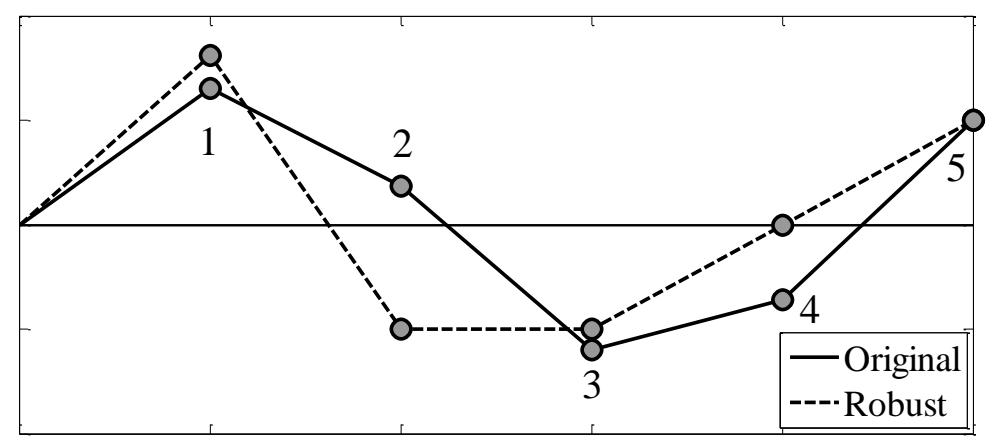

Fig. 7 Comparison of $3^{\text {rd }}$ eigen mode between original and robust structure. It shows that it has changed the strucuture, which the noise factor does not stretch by robust optimization.

\section{4. 有限要素モデルへのロバスト最適化の適用と実験による検証}

本章では図 8 に示寸簡易有限要素モデルを用い，実際の機械製品で見られるような板厚のバラツキを想定し， ロバスト最適化を適用する．また簡易有限要素モデルと同様の試験片を用意し，実験でロバスト最適化の有効性 を検証する. 本適用例では誤差因子を複数個存在する事例を扱うことにより, 複数の誤差因子に対してもロバス 卜最適化が効果的に機能することを示す. 前章と同様, 固有振動数の変動の大きさの比較には平均值, 標淮偏差, 変動係数を用いる.

\section{$4 \cdot 1$ 有限要素モデルへのロバスト最適化の適用}

図 8 に対象とする簡易有限要素モデルを示寸. 対象モデルは片端が完全拘束されている片持ち梁で, 長さ $l=300$ $\mathrm{mm}$, 幅 $w=50 \mathrm{~mm}$, 板厚 $t=10 \mathrm{~mm}$ である. 有限要素モデルは $5 \times 5 \mathrm{~mm}$ の四角形要素で構成されており, 図 8 に示 すように梁が 9 つのコンポーネントから成り立っていると考える. 板厚のバラツキを想定し, 誤差因子をコンポ 一ネント $1,4,5$ の板厚 $t_{i}$ とし, 制御因子はその他のコンポーネントの板厚 $t_{j}$ とする. また誤差因子の総体積と 制御因子の総体積は同一とする．材料はアルミニウムとした.

今回は曲げ 2 次固有振動数 $f_{b 2}$ をロバス卜設計の対象とし, 板厚がバラツいた際の 2 次曲げ固有振動数の変動を 最小化するロバスト設計を行う. 制御因子の許容変化量を $\pm 50 \%$, 制御因子の板厚の和は最適化前と同一（質量 一定）の条件下で最適化計算を行う。

図 9 に構造最適化による 1 次感度の推移を示寸. また表 5 にロバスト構造の制御因子の值を示し, 図 10 に板厚 の外観を示す. 図 9 より, 最適化計算によりすべての䛊差因子の一次感度が減少し, ある一定值に収束している 様子が確認できる. これより, 複数の誤差因子に対してもロバスト最適化が安定的に機能しており, 効果的であ ることがわかる. 3 章でのバネマス系の検証と比較して誤差因子の一次感度はゼロまで収束していないが, これ は表 5 に示すように, 制御因子が最適化計算の最大許容変化量まで変化したためである. 許容变化量を大きくす ることで，一次感度をさらに小さくすることが可能であることを検証済みである.

一次感度の減少により固有振動数の変動が抑制されたかを, 初期構造, ロバス卜構造の誤差因子 $t_{i}$ に $20 \% の$ 幅でバラツキを与え, $N=300$ 回計算を行った. 表 6 に曲げ 2 次固有振動数の変動の大きさの比較を示し, 図 11 に FRF の変動の比較を示す. FRF の入力点, 応答点は図 8 に示すように, コンポーネント 2, 9 の z 方向とする. 表 6 より, 構造最適化で固有振動数の増減の条件は付与していないが, ロバスト構造では 2 次曲げ固有振動数が $541.1 \mathrm{~Hz}$ から $370.8 \mathrm{~Hz}$ 一約 $31 \%$ 減少した. 変動係数を比較すると, ロバス卜構造では初期構造と比較して曲げ 2 次の固有振動数の変動が $6.58 \%$ から $2.34 \%$ 約 $64 \%$ 低減されたことがわかる. また図 11 からも曲げ 2 次固有振 動数の変動が抑制されている様子が確認できる.

3 章でのバネマス系の検証と同様に, ロバスト構造の物理的な特徵を固有モードから考察する. 図 12 に初期構 造, ロバスト構造の固有モードの比較を示す. なお, 図(c)は固有モードを比較し易くするため, 固定点からみて 最初に現れる振動の腹を 1 とするように正規化している. 図 12 より, ロバスト構造では誤差因子のコンポーネン 
卜 $1 ， 4 ， 5$ 内で曲げ変形が小さくなるよう，コンポーネント内での変位の変化が線形的（変位の変化勾配が小さ い）になるような構造に変化している．これより板厚が誤差因子に場合には上記のような構造的特徵があり，こ のような構造設計を行うことで, 固有振動数の変動に対するロバスト設計を行うことが可能である.

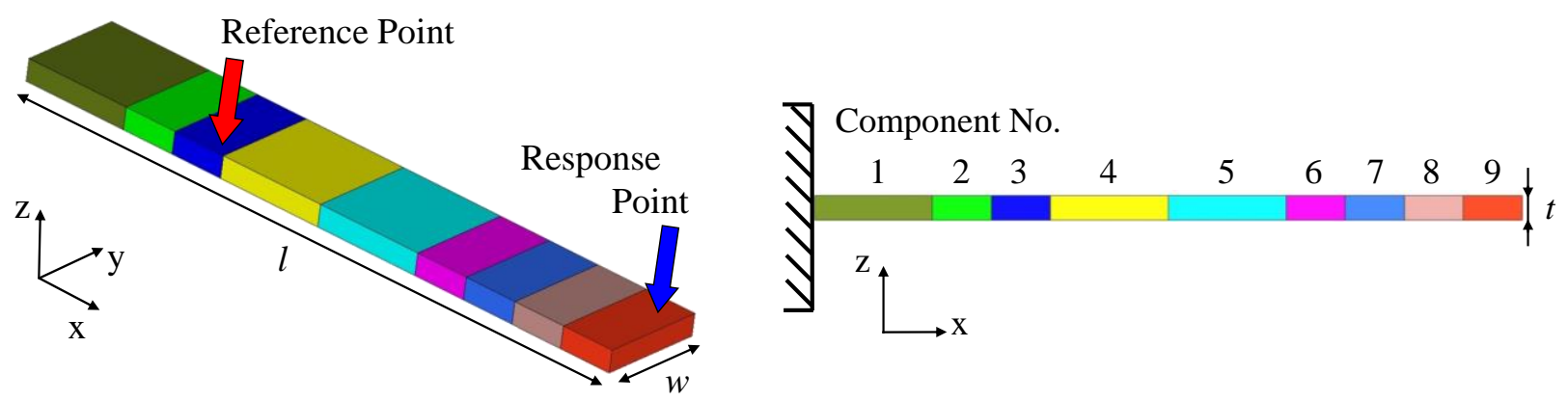

Fig. 8 FE model

Table 5 Change of control factor parameter [mm]

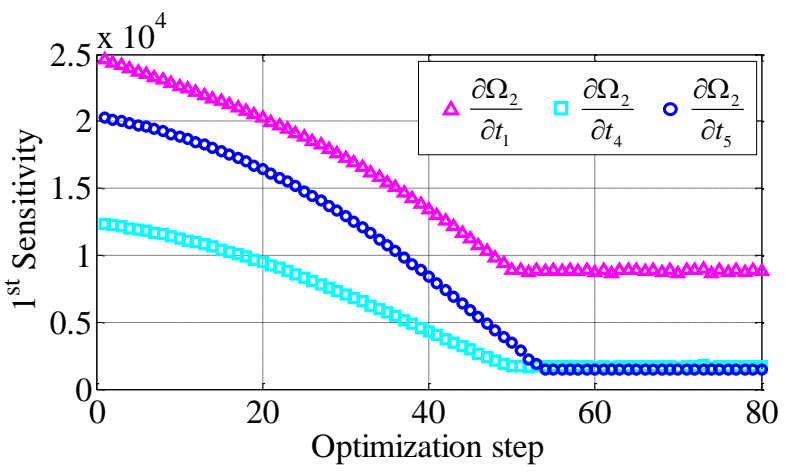

Fig. $9 \quad 1^{\text {st }}$ sensitivity under robust optimization. It shows that robust optimization is performed stably.

\begin{tabular}{|c|c|c|c|c|c|c|}
\hline & $\mathrm{t}_{2}$ & $\mathrm{t}_{3}$ & $\mathrm{t}_{6}$ & $\mathrm{t}_{7}$ & $\mathrm{t}_{8}$ & $\mathrm{t}_{9}$ \\
\hline Original & 10.00 & 10.00 & 10.00 & 10.00 & 10.00 & 10.00 \\
\hline Robust & 5.00 & 15.00 & 5.00 & 5.00 & 15.00 & 15.00 \\
\hline
\end{tabular}

\section{Component No.}

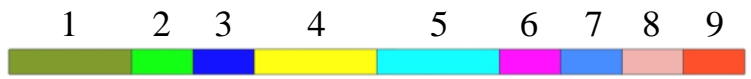

(a) Original structure

(b) Robust structure

Fig. 10 Thickness form

Table 6 Comparison of the robustness at $2^{\text {nd }}$ bending eigen frequency. It shows that the robustness is improved by comparing $C v$.

\begin{tabular}{|c|c|c|c|c|}
\hline & $f_{b 2}[\mathrm{~Hz}]$ & $M\left(f_{b 2}\right)[\mathrm{Hz}]$ & $\sigma\left(f_{b 2}\right)[\mathrm{Hz}]$ & $C v\left(f_{b 2}\right)[\%]$ \\
\hline Original & 545.1 & 542.7 & 35.43 & 6.58 \\
\hline Robust & 370.8 & 367.8 & 8.7 & 2.34 \\
\hline
\end{tabular}

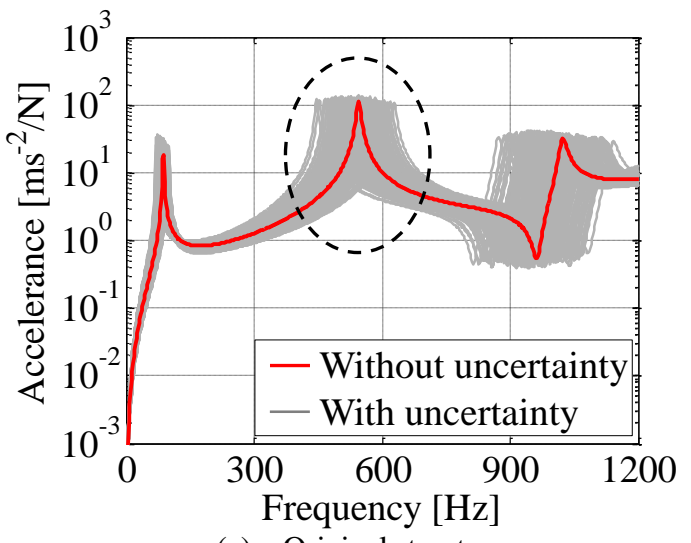

(a) Original structure

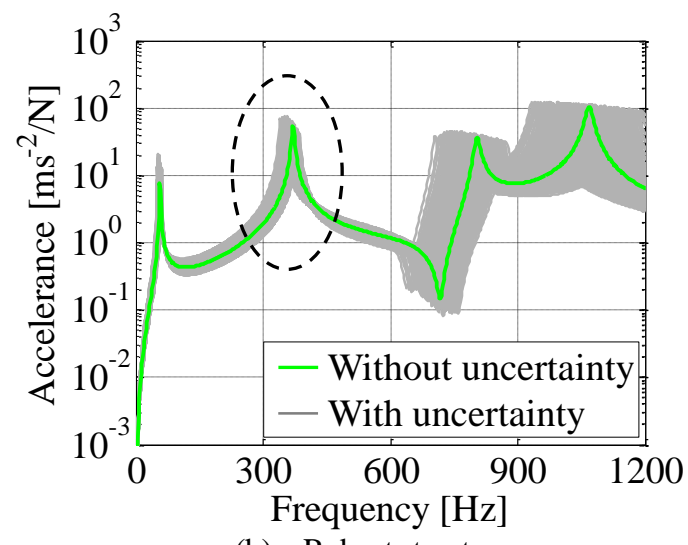

(b) Robust structure

Fig. 11 Comparison of FRF variation between original and robust structure. It shows that $2^{\text {nd }}$ bending eigen frequency variation is suppressed. 

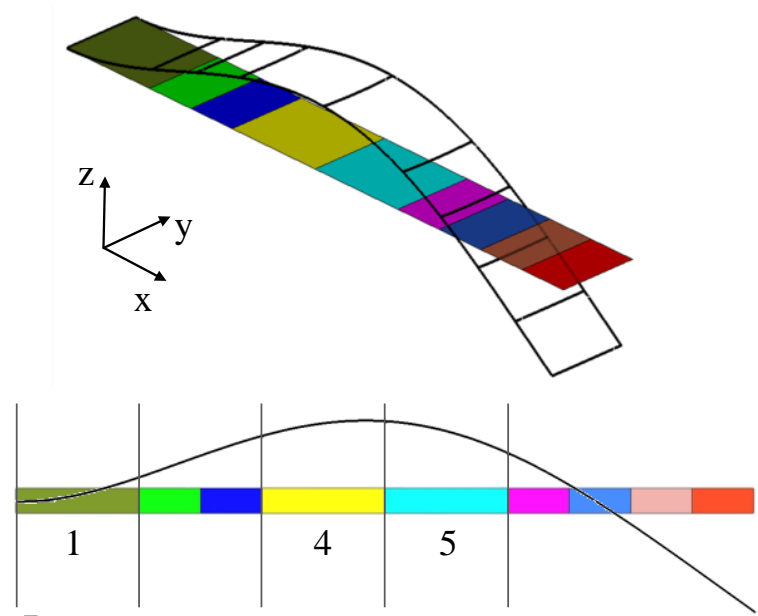

$\stackrel{\mathrm{Z}}{\longrightarrow} \mathrm{X}$

(a) Original structure
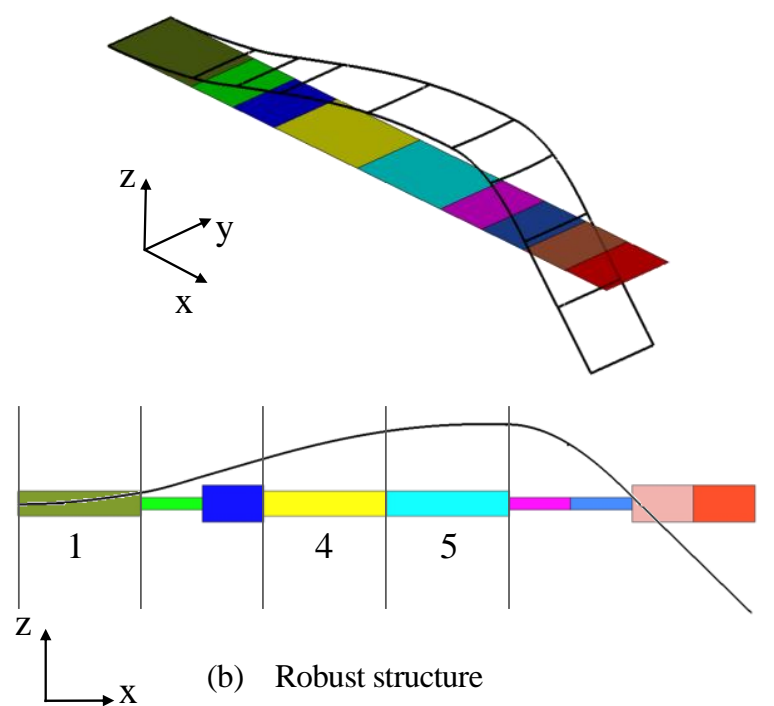

(b) Robust structure

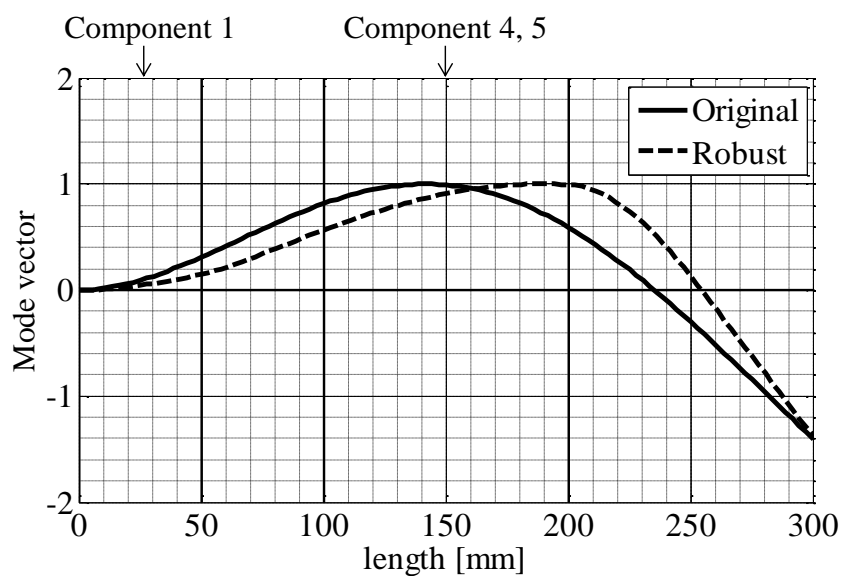

(c) Comparison original and robust structure in xz plan

Fig. 12 Comparison of $2^{\text {nd }}$ bending eigen mode between original and robust structure. It shows that it has changed the strucuture, which the noise factor does not occur bending moment by robust optimization.

\section{$4 \cdot 2$ 実験によるロバスト最適化の効果の検証}

$4 \cdot 1$ 節の有限要素モデルの結果に基づき， ロバスト最適化前後のモデルと同形状の試験片を作成する．そして 作成した試験片を用いた実験により，4・1 節と同様，ロバスト構造は誤差因子の板厚のバラツキによる曲げ 2 次 固有振動数の変動が抑制されているかを検証する.

作成した試験片は有限要素モデルと同条件でバラツキを与えるため, 誤差因子にあたるコンポーネント $1 ４$, 5 の部分の板厚を初期板厚 $10 \mathrm{~mm}$ から+20\%厚く $12 \mathrm{~mm}$ で作成した. 誤差因子のバラツキによる 2 次曲げ固有振 動数の変動の計測は，誤差因子にあたるコンポーネント 1，4，5 の部分を順に $0.5 \mathrm{~mm}$ ずつ削り，その都度振動 特性の計測を行い, そしてすべての誤差因子の板厚が初期板厚から-20\%薄い $8 \mathrm{~mm}$ になるまで計 24 回繰り返し 計測を行う.これを初期構造とロバスト構造の両方で行い, 結果の比較を行う. 図 13 に実験セットアップと作成 した試験片を示す（図 13(a)に示寸初期構造は削る前，(b)に示寸ロバスト構造は削り後の図である)，なお，実験 はハンマリングによる加振実験を行う.

表 7 に初期構造，ロバスト構造の 2 次曲げ固有振動数の変動の大きさの比較を示し，図 14 に計測毎の FRF の 変化を示す. なお図 14 は図 13 に示す加振点, 応答点間の FRFである. 表 7 の変動係数を比較すると, ロバスト 構造では初期構造と比較して 2 次曲げの固有振動数の変動が $6.38 \%$ か $2.18 \%$ 約 66\%低減されたことがわかる. これは有限要素法の結果とほぼ同様の結果であり, 固有振動数の変動が抑制できていることがわかる. また図 14 からも曲げ 2 次固有振動数の変動が抑制されている様子が確認できる. 
以上より，作成した試験片においてもロバスト構造は誤差因子のバラツキによる固有振動数の変動が抑制でき ており，実構造物においても提案したロバスト最適化が有効であることが確認できた.

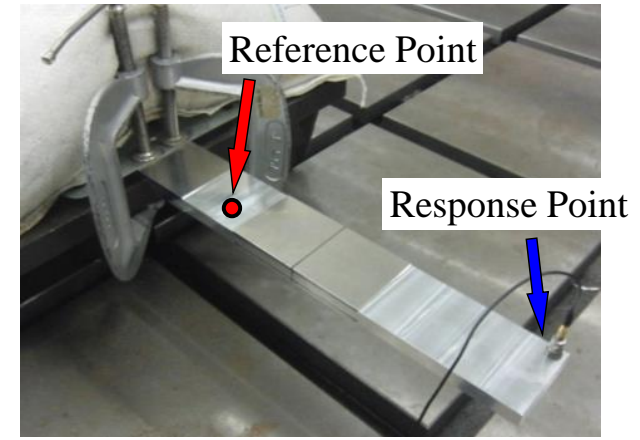

(a) Original structure

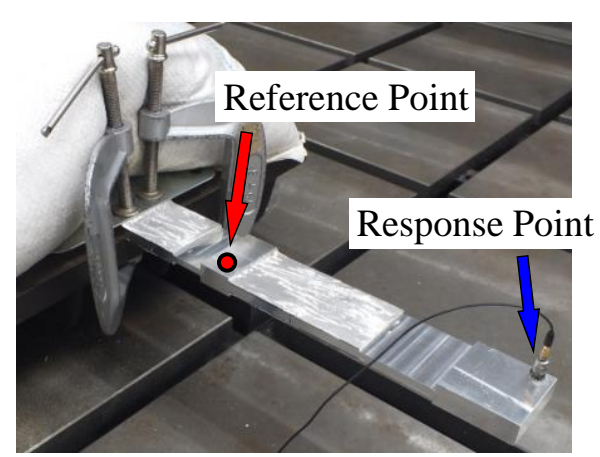

(b) Robust structure

Fig. 13 Experiment setup and test pieces

Table 7 Comparison of the robustness at $2^{\text {nd }}$ bending eigen frequency by experiment result. It shows that the robustness is improved by comparing $C v$.

\begin{tabular}{|c|c|c|c|}
\hline & $M\left(f_{b 2}\right)[\mathrm{Hz}]$ & $\sigma\left(f_{b 2}\right)[\mathrm{Hz}]$ & $C v\left(f_{b 2}\right)[\%]$ \\
\hline Original & 561.1 & 35.8 & 6.38 \\
\hline Robust & 371.8 & 8.1 & 2.18 \\
\hline
\end{tabular}

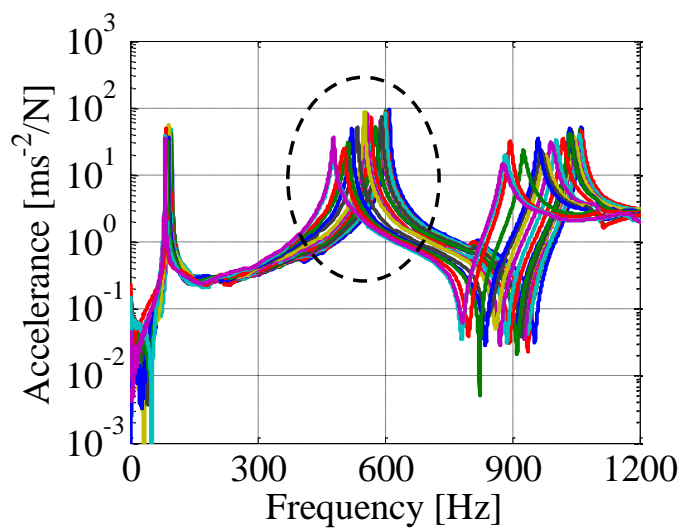

(a) Original structure

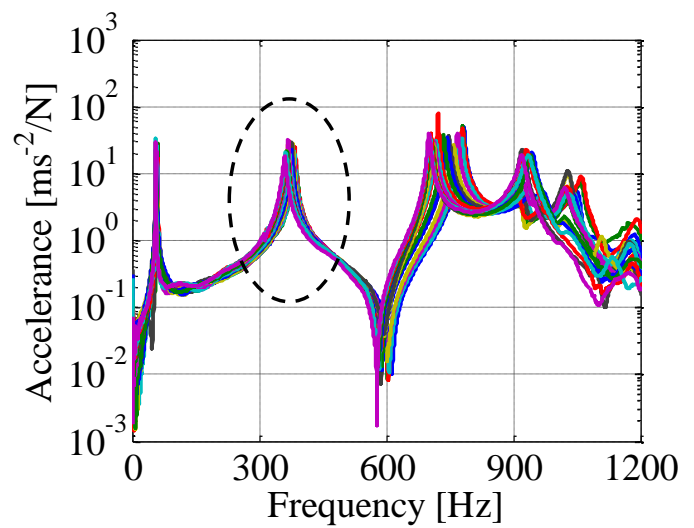

(b) Robust structure

Fig. 14 Comparison of FRF variation between original and robust structure by expwriment result. It shows that $2^{\text {nd }}$ bending eigen frequency variation is suppressed.

\section{5. 結 語}

本論文では誤差因子のバラツキによる固有振動数の変動を最小化することを目的に, 確率有限要素法と構造最 適化を組み合わせたロバスト最適化によるロバス卜設計を提案した。本論文で得られた知見を以下にまとめる.

(1) 確率有限要素法と構造最適化を組み合わせたロバスト最適化を提案し，固有振動数の変動を最小化する 際の理論を整理した。ロバスト最適化は誤差因子の固有振動数に対する一次感度を最小化する方法で, 固有振動数の一次感度を最小化する逐次線形計画法を解く際に利用する固有振動数の一次感度および二 次感度を導出した.

(2) バネマス系において誤差因子が質量, 剛性の場合にロバスト最適化を適用し, 固有振動数の変動を抑制 可能であることを示した．また固有振動数の変動が最小化されたロバス卜構造は，質量が誤差因子の場 合に対象とした固有モードにおいて誤差因子が節点となる構造的特徵があり, 剛性が誤差因子の場合に 固有モードにおいてバネが伸縮しない構造的特徴があることを示した. 
（3）有限要素モデルにおいて誤差因子が板厚の場合にロバスト最適化を適用し，固有振動数の変動を抑制可 能であることを示した．また誤差因子が複数個存在する場合もロバスト最適化が効果的に機能すること を示した．さらに板厚が誤差因子の場合のロバスト構造は，対象とする固有モードにおいて誤差因子の コンポーネント内の変位の変化が線形的となる構造的特徴があることを示した.

（4）有限要素モデルの結果に基づき，ロバスト最適化前後のモデルと同形状の試験片を作成し，実験を行う ことにより，実構造物においてもロバスト最適化が有効であることを示した.

\section{文献}

Durand, J., Gagliardini, L. and Soize, C., Nonparametric modeling of the variability of vehicle vibroacoustic behavior, SAE Noise and Vibration Conference and Exhibition Proceedings (2005), 2005-01-2385.

古屋耕平, 坂本順, 片桐章彦, 戸井武司, 周波数応答関数の変動最小化を目的とした確立有限要素法に基づくロバ

ス卜設計法, 日本機械学会論文集, Vol. 80, No. 810 (2014), DOI:10.1299/transjsme.2014dr0030.

萩原一郎, 藤原稔久, 永㴊和夫, 構造物の振動特性向上のための最適化解析, 第 1 法, 新しい固有モード感度解析

手法の提案と異なる解析手法の比較, 日本機械学会論文集 C 編, Vol. 52, No. 482 (1986), pp. 2607-2616.

廣安知之, 岡洋介, 木村光宏, 山川宏, ロバスト構造に関する研究, 第3 報, 動的ロバスト構造の設計法と検討, 日 本機械学会論文集 A 編, Vol. 62, No. 594 (1996), pp. 482-487.

星野裕昭, 石井英章, 音響特性の改善のための品質工学によるロバスト設計, 日本機械学会論文集 C編, Vol. 66,

No. 645 (2000), pp. 1509-1516.

中桐滋, 久田俊明, 確率有限要素法入門 (1985), pp.20-34, 培風館.

山川宏, 奥村敦史, 振動を考慮した構造物の最適設計について, 第 1 報, 最適設計の一般的な方法, 日本機械学会 論文集, Vol. 42, No. 365 (1976), pp. 1109-1118.

\section{References}

Durand, J., Gagliardini, L. and Soize, C., Nonparametric modeling of the variability of vehicle vibroacoustic behavior, SAE Noise and Vibration Conference and Exhibition Proceedings (2005), 2005-01-2385.

Furuya, K., Sakamoto, J., Katagiri, A. and Toi, T., Robust design to minimize FRF variance of structure by stochastic finite element method, Transactions of the JSME(in Japanese), Vol. 80, No. 810 (2014), DOI:10.1299/transjsme.2014dr0030.

Hagiwara, I., Fujiwara, T. and Nagabuchi, K., Optimum analysis for structural vibration character, 1st report, Proposition of a new eigen mode sensitive analysis and comparison between some different methods, Transactions of the Japan Society of Mechanical Engineers, Series C, Vol. 52, No. 482 (1986), pp. 2607-2616 (in Japanese).

Hiroyasu, T., Oka, Y., Kimura, M. and Yamakawa, H., Study on robust structures, 3rd report, Design method and discussions on dynamic robust structure problems, Transactions of the Japan Society of Mechanical Engineers, Series A, Vol. 62, No. 594 (1996), pp. $482-487$ (in Japanese).

Hoshino, H. and Ishii, H., The robust design for acoustic characteristic modification with taguchi method, Transactions of the Japan Society of Mechanical Engineers, Series C, Vol. 66, No. 645 (2000), pp. 1509-1516 (in Japanese) .

Nakagiri, S. and Kubota, T., Introduction to stochastic finite element method (1985), pp.20-34, BAIFUKAN (in Japanese).

Yamakawa, H. and Okumura, A., On the optimal design of structures in vibrating state, 1st report, A general method of optimal design, Transactions of the Japan Society of Mechanical Engineers, Vol. 42, No. 365 (1976), pp. 1109-1118 (in Japanese). 